\title{
RITUAL SEBAGAI MEDIA TRANSMISI KREATIVITAS SENI DI LERENG GUNUNG MERBABU
}

\author{
Rr. Paramitha Dyah Fitriasari \\ Program Studi Pengkajian Seni Pertunjukan dan Seni Rupa \\ Sekolah Pascasarjana Universitas Gadjah Mada \\ Email : paramitha_df@yahoo.com \\ Timbul Haryono \\ Jurusan Arkeologi Fakultas Ilmu Budaya Universitas Gadjah Mada \\ G.R. Lono Lastoro Simatupang, Irwan Abdullah \\ Jurusan Antropologi Fakultas Ilmu Budaya Universitas Gadjah Mada
}

\begin{abstract}
Tradition developed in a community should continue to be preserved from generations to generations. Efforts are being made one of which is the process of transmission or inheritance. Transmission can be done in various ways, one of which is ritual. Rituals which are performed continuously and regularly can be a good medium for the transmission process. The ritual process of artistic creativity that was developed by the community on the slopes of Mount Merbabu is an example. Art goes hand in hand with the ritual is one of the transmission mediums used to continue an existing tradition. This research seeks to show how ritual can be a transmission medium of art, particularly on the slopes of Merbabu.
\end{abstract}

Keywords : Rituals, Transmission, Art Creativity

\begin{abstract}
ABSTRAK
Tradisi yang berkembang dalam sebuah kelompok masyarakat harus terus dilestarikan oleh generasi penerus dari generasi terdahulu. Upaya yang dilakukan salah satunya dapat melalui proses transmisi atau pewarisan. Transmisi dapat dilakukan dengan berbagai cara, salah satunya melalui ritual. Ritual yang terus menerus dan rutin dilakukan dapat menjadi media yang baik dalam proses transmisi. Melalui ritual proses kreativitas seni yang dikembangkan oleh masyarakat di lereng Gunung Merbabu juga dapat berjalan dengan baik. Seni yang berjalan beriringan dengan ritual dapat menjadi salah satu media transmisi untuk dapat meneruskan tradisi yang sudah ada. Penelitian ini akan menjawab bagaimana ritual dapat menjadi media transmisi kreativitas seni tepatnya di Lereng Gunung Merbabu.
\end{abstract}

Kata Kunci : Ritual, Transmisi, Kreativitas Seni

\section{PENGANTAR}

Geertz menyatakan bahwa sepanjang sejarah gunung-gunung api di Pulau Jawa selalu dipadati pemukiman penduduk karena merupakan sumber bagi kehidupan, yaitu menyuburkan tanah pertanian melalui air mineral dan abu vulkanik. Gambaran di atas menunjukkan bahwa adanya hubungan 
antara manusia dan gunung (Geertz, 1976: 33). Faktor-faktor kebudayaan dengan wujud kesenian seperti gerak, rupa, suara, dan lainlain yang menjadi latar belakang keharmonisan tampak melekat dalam sanubari masyarakat di daerah pegunungan. Hampir semua desa di Lereng Merbabu, mempunyai agenda seni budaya, yang sebagian besar berhubungan dengan ritual terhadap alam dan lingkungan sekitarnya. Ada pendapat bahwa masyarakat pegunungan cenderung hidup di dalam kelompok dan kurang berinteraksi dengan dunia luar (Firmansyah, 2007: 87). Kehidupan masyarakat gunung juga dianggap masih terisolir dan pendidikannya rendah, namun ini sangat berbeda keadaannya dengan masyarakat di lereng Gunung Merbabu. Meski memang sebagian besar mata pencahariannya sebagai petani, namun semangat dan kekuatan untuk menjaga eksistensi seni mereka sangat besar.

Lereng gunung Merbabu di sini adalah difokuskan pada daerah yang masuk ke dalam wilayah administratif Kecamatan Pakis, Kabupaten Magelang. Dalam satu kecamatan mempunyai 20 desa, 165 dusun. Rata-rata setiap desa kurang lebih mempunyai lima grup kesenian, sehingga dengan kata lain satu Kecamatan mempunyai kurang lebih 100 grup kesenian, walaupun satu jenis kesenian dapat dimainkan oleh beberapa grup yang berbeda-beda. Kesenian tersebut di antaranya adalah soreng, topeng ireng, warok bocah, kuda lumping, dan lain-lain. Namun perlu digarisbawahi bahwa jumlah tersebut masih berupa hitungan jumlah kesenian yang tercatat, jadi ada jenis kesenian yang hidup, berkembang, tidak berkembang, bahkan mati. Kesemuanya itu sangat diperlukan pendukung agar kesenian yang sudah ada di suatu wilayah dapat berkembang dan tidak mati ditelan perkembangan zaman.

Upaya pelestarian sangat gencar dilakukan oleh beberapa pihak atau instansi terkait, namun ketika tidak mendapat dukungan dari masyarakat sekitar yang berhubungan langsung dengan tumbuh kembangnya seni tersebut, maka semua itu tidak akan ada artinya. Masyarakat lereng Gunung Merbabu dapat dikatakan masih dalam lingkup tradisional, baik dalam mata pencaharian mereka ataupun dari sikap dan perilaku yang masih sangat kental dengan kehidupan agraris. Akan tetapi, dalam kehidupan kesenian seperti yang sudah dipaparkan di atas, dan jika mengacu pada pendapat Alex Inkeles, mereka dapat dianggap sebagai kelompok orang yang modern. Ciri-ciri orang modern yang sudah melekat dalam diri mereka, di antaranya adalah kesediannya untuk menerima pengalaman-pengalaman yang baru dan keterbukaannya bagi pembaharuan dan perubahan (Inkeles, 1983: 87). Mereka juga mau belajar untuk mendapatkan hasil yang lebih maksimal, tidak hanya sekedar menerima dari pendahulunya dalam hal ini mereka berusaha untuk menambah kreativitas mereka di bidang seni. Terakhir adalah kehidupan kesenian mereka sangat teroganisir, walaupun masingmasing kelompok mempunyai cara yang berbeda untuk mengatur manajemen kelompok keseniannya.

Masyarakat Gunung hidup dengan sistem sosial yang terbuka. Kelonggaran sistem sosial menyebabkan keadaan yang oleh Edi Sedyawati disebut "dinding antar golongan telah berpintu tembus" (Sedyawati, 1985). Keadaan serupa memungkinkan terjadinya tular menular nilai kesenian. Elemen-elemen dalam kesenian tradisional memang dapat dikatakan peluang untuk berubah karena tidak ada aturan khusus atau pakem yang harus dipatuhi. Berbeda halnya dengan seni istana atau seni keraton yang masih terikat kuat oleh pakem, bahkan beberapa di antaranya sangat jelas tertuang di naskah kuno. Oleh karena itu, seni tradisi sangat bergantung dengan masyarakat pendukungnya ketika masyarakat menginginkan adanya perubahan, maka otomatis kesenian juga akan ikut berubah.

Seperti yang diungkapkan juga oleh Edward Shils dalam bukunya Tradition bahwa sebenarnya tradisi yang diturunkan 
dari generasi ke generasi itu sudah melalui proses perubahan dalam bentuk apapun dan sekecil apapun sudah dimodifikasi oleh generasi penerima (Shils, 1981: 12-15). Setiap masyarakat memiliki bentuk seni tertentu, mulai dari masyarakat sederhana sampai yang modern. Dalam komunitas masyarakat yang sederhana, seni cenderung dipandang sebagai ekspresi budaya. Sebagai ekspresi dan produk budaya, seni berkaitan dengan sistem sosial masyarakat pendukungnya.

\section{PEMBAHASAN \\ Transmisi dan Pewarisan Tradisi}

Kesenian tradisi yang memang diterima sebagai tradisi yang melalui proses pewarisan ini tidak murni dapat diterima begitu saja.

... tidak ada bentuk pewarisan karya seni atau naluri berkesenian yang secara 100\% diwariskan oleh suatu generasi ke generasi berikutnya, karena sesungguhnya setiap generasi atau kelompok dalam masyarakat secara khusus memiliki intepretasinya sendiri dan memberi makna pada zamannnya (Paeni, 1995 : 21).

James R. Brandon dalam bukunya Jejak-jejak Seni Pertunjukan di Asia Tenggara, menjelaskan bahwa bentuk dan formula seni pertunjukan di Asia Tenggara dilestarikan dan dialihkan kepada generasi penerus dengan dua jenis proses transmisi yaitu transmisi tradisional dan transmisi modern (Brandon, 2003; 212). Proses transmisi tradisional pada umumnya tidak terstruktur dan informal, seperti misalnya seorang pemuda duduk dibelakang pentas, sambil melihat, mendengarkan, maka ia sekaligus belajar. Proses transmisi tradisional yang sering dilakukan oleh seseorang yang ingin belajar bersama orang (tokoh) yang dianggap sudah terkenal atau ahli dibidangnya adalah dengan cara nyantrik, yaitu dengan mengikuti semua kegiatan tokoh tersebut bahkan tinggal dalam kehidupan sehari-hari sang tokoh.

Proses penciptaan sebuah kesenian adalah secara tidak langsung juga sekaligus merupakan warisan dari nenek moyang yang tidak dapat semata-mata muncul secara tiba-tiba. Kehadiran seni tari di Magelang merupakan keberlangsungan kehidupan kultural yang diduga sudah berakar sejak dulu. Setiap zaman melahirkan pola dan bentuk kesenian yang berbeda, sejalan dengan cara pandang mereka terhadap kehidupan dan bagaimana mereka mengekspresikan ke dalam ragam bentuk aktivitas seni. Namun, mempertahankan kebudayaan yang ada penting dengan langkah menyesuaikan perkembangan zaman tanpa mengubah ciri atau jati diri kebudayaan yang ada. Manusia selain menghasilkan kebudayaan, juga harus mampu mewariskan pengetahuan yang dimiliki kepada generasi penerus.

Proses transmisi atau pewarisan dari generasi sebelumnya adalah langkah yang paling mudah untuk tetap melestarikan sebuah kesenian. Fortes mengungkapkan bahwa transmisi adalah proses belajar dengan meniru orang yang lebih tua dan mengidentifikasikan diri dengan berperan serta dalam kegiatan sehari-hari (Koentjaraningrat, 1990: 215). Transmisi merupakan salah satu cara untuk mempertahankan keberlangsungan sebuah kesenian, tidak hanya bentuk melainkan nilainilai moral yang terkandung di dalamnya. Proses ini terjadi secara alamiah sebab terjadi dalam kehidupan sehari-hari dan tanpa paksaan.

Pewarisan kesenian di beberapa daerah tidak bisa secara otomatis berlaku bagi semua orang, dan melalui berbagai cara dan tidak sama bagi setiap jenis kesenian. Jika merujuk pada pendapat Masunah bahwa proses pewarisan dari adat istiadat desa serta didukung oleh masyarakat sesuai kondisi lingkungan, tradisi serta kepercayaan setempat (Masunah, 2003: 228). Masyarakat di lereng Gunung Merbabu juga melakukan pewarisan melalui adat dan kepercayaan masyarakatnya yaitu salah satunya dengan melakukan ritual.

Ritual sebagai tradisi yang masih terus berlangsung tidak akan dirubah bentuk 
dan elemen pendukungnya, seperti waktu, tempat dan sesaji yang menyertainya. Akan tetapi, tambahan unsur pendukung seperti kesenian yang disajikan dalam ritual tersebut dapat menambah kreasi para pendukungnya untuk lebih menambah semarak ritual tersebut tanpa mengurangi kesakralannya. Transmisi atau pewarisan yang terjadi di masyarakat lereng Gunung Merbabu ada dua aspek yang bisa diwariskan yaitu aspek bentuk dan aspek nilai serta religi. Aspek bentuk meliputi tarian, musik atau lagu, dan pengelolaan grup kesenian, sementara aspek nilai dan religi juga ditekankan sejak dini baik tergabung dengan grup kesenian maupun bukan. Kebiasaan atau adat istiadat yang sudah ada di wilayah desa tertentu sudah mulai dikenalkan dan diwariskan kepada generasi penerus agar dapat terus berjalan dan tidak hilang dimakan zaman.

Johanes Mardimin menyatakan bahwa seni tradisi bukanlah benda mati, dengan demikian seniman dituntut untuk selalu pandai menyesuaikan diri. Pelestarian tidak mempunyai keharusan untuk mempertahankan seni seperti semula. Perubahan bisa dilakukan dengan membenahi salah satu atau beberapa bagian yang dirasa tidak memenuhi selera masa kini (Mardimin, 1994: 146). Dalam hal ini pewarisan tradisi memang sudah seharusnya dilakukan oleh generasi sebelumnya kepada generasi penerus, namun bagaimana generasi penerus menerima atau mengintepretasikan dengan cara yang sama atau berbeda tergantung dari generasi penerus dalam menerima sesuai dengan keadaaan zamannya. Aspek yang dapat ditransmisikan ada dua hal yaitu bentuk dan nilai. Aspek bentuk sudah dapat dipastikan harus ditransmisikan karena meliputi inti dari sebuah kesenian tersebut, di antaranya adalah tema, gerak, rias dan busana, iringan, durasi waktu, dan pelaku seni. Aspek yang kedua adalah nilai, tata aturan yang ada dalam suatu masyarakat memiliki nilai dan norma yang bertujuan untuk menunjang ketentraman bermasyarakat.
Nilai yang dapat ditransmisikan ada tiga yaitu nilai kedisiplinan, nilai kebersamaaan, dan nilai penjiwaan. Pertama, nilai kedisiplinan dapat dimulai dengan menanamkan bahwa setiap gerakan harus dilakukan dengan benar seperti yang telah ditentukan, sehingga gerak antara penari yang satu dengan yang lain dapat terlihat sama. Selain dalam gerak, kedisiplinan juga harus diterapkan dalam waktu saat latihan atau akan pentas. Jam berapa penari dan kru harus datang ke lokasi pertunjukan, dengan perkiraan waktu pentas yang telah ditentukan, sangat dilarang datang mendekati waktu pentas. Jika merias atau menyiapkan diri secara tergesa-gesa dapat mengakibatkan hal yang tidak baik. Misalnya karena terburu-buru pakaian yang digunakan kurang pas, atau karena belum bersiap-siap, maka sebelum pentas sudah kelelahan. Kedisiplinan yang diterapkan dalam tari diharapkan juga dapat diterapkan dalam kehidupan sehari-hari.

Kedua, nilai kebersamaan adalah setiap gerakan dalam tarian akan terlihat lebih menarik apabila dilakukan secara bersamasama. Tarian yang hidup di lereng Gunung Merbabu sebagian besar merupakan jenis tarian berkelompok. Kekompakan gerak penari sangat diutamakan, oleh sebab itu secara tidak langsung mengajarkan nilai kebersamaan kepada para penari untuk dapat saling merasakan kebersamaan antara mereka. Selain disiplin yang tinggi, hubungan satu penari dengan yang lain juga sangat menentukan kekompakan. Ketika hubungan tersebut dapat berjalan baik dan tidak ada satu permasalahan apapun maka hasil dari gerak dan kreasi mereka dalam mementaskan kesenian akan sangat terlihat rapi dan bagus. Ketika ada masalah yang menyangkut dengan kelompok kesenian akan lebih baik jika langsung dibicarakan bersama secara terbuka, sehingga diharapkan tidak ada yang memendam dalam hati masalah yang dihadapi. Melalui kebersamaan yang kuat hasil yang akan dicapai akan lebih maksimal. 
Ketiga, nilai penjiwaan. Penjiwaan menjadi unsur penting dalam menari, tidak hanya asal menggerakan tubuh. Penari akan lebih bagus apabila bisa menjiwai dan merasakan tarian itu dalam diri. Ekspresi penari akan Nampak apabila dari dalam juga menjiwai karakter yang ditampilkan. Secara nyata penjiwaan adalah nilai yang paling sulit untuk ditransmisikan, sebab penjiwaan seorang penari akan tergantung dari pribadi masing-masing dalam membawakan tarian. Ekspresi penari dapat saja diajarkan dan dipelajari namun ketika peran dalam tarian itu dapat masuk ke jiwa penari akan membutuhkan waktu yang relatif lama. Melalui pengalaman pentas, mereka akan menemukan roso atau jiwa dalam tarian tersebut sehingga dalam menggerakan badan akan terlihat lebih ekspresif.

Media transmisi yang dilakukan di lereng Gunung Merbabu sebagian besar adalah melalui media non-formal seperti melalui masyarakat dan keluarga. Media non-formal pertama adalah keluarga bahwa peran keluarga merupakan lingkup paling kecil dari sebuah kelompok masyarakat sangat menentukan pertumbuhan dan perkembangan dari usia anak-anak sampai usia dewasa. Terutama pada anak-anak adalah dasar dari pembentukan mental dan moral yang dapat diajarkan dan ditanamkan oleh keluarganya dalam hal ini adalah orang tua. Pengenalan nilai agama, budi pekerti, bahkan sampai kesenian dapat dimulai dari keluarga. Oleh karena itu, keluarga akan berpengaruh penting pada proses transmisi kesenian sebab ketika keluarga tidak mengenalkan atau melarang anak atau anggota keluarga mengenal kesenian, maka proses transmisi tidak akan berjalan.

Media non-formal kedua adalah masyarakat bahwa pendukung dari kesenian yang paling nyata adalah masyarakat baik yang terlibat langsung sebagai penari, pemusik, atau seluruh anggota masyarakat yang tinggal di wilayah Lereng Gunung merbabu. Komunikasi yang terjadi antara generasi akan sangat mendukung kelancaran proses transmisi, bahkan kesediaan masyarakat tanpa adanya unsur paksaan juga sangat berpengaruh. Interaksi yang terjalin antar-anggota masyarakat akan sangat menentukan keberlangsungan hidup sebuah kesenian dan mereka dapat saling bahu membahu mempertahankan apa yang sudah menjadi warisan dari leluhur mereka sebagai penyangga kesenian, masyarakat harus memahami maksud dan tujuan sebuah kesenian, maka mereka akan lebih menghargai kesenian yang ada.

\section{Ritual sebagai Media Transmisi}

Seni pertunjukan dalam kehidupan manusia, bukanlah produk dari satu bagian masyarakat saja melainkan telah berkembang di banyak lingkungan sosial. Salah satunya yang berhubungan dengan kehidupan rakyat desa, terlebih yang berlatar belakang petani. Dalam kehidupan masyarakat petani tradisional, lahirnya seni pertunjukan berhubungan dengan kepercayaan atau ritual tertentu. Pelaksaannya berdasarkan waktuwaktu tertentu, atau pada saat kejadiankejadian tertentu. Salah satu proses transmisi yang paling kuat adalah melalui ritual karena ritual otomatis masyarakat meneruskan tradisi yang sudah ada.

Upacara yang dilakukan oleh masyarakat Pakis biasanya berkaitan erat dengan ritual yang rutin dilakukan untuk menghormati roh nenek moyang yang telah mendahului masyarakat Pakis. Seperti yang sudah dipaparkan bahwa masyarakat Pakis rutin menyelenggarakan upacara ritual dengan menggelar kesenian sebagai salah satu syarat yang harus dipenuhi dalam rangkaian ritual tersebut. Dengan kata lain upacara tidak dapat dilangsungkan tanpa kehadiran seni pertunjukan. Upacara dianggap tidak sah apabila tidak disertai dengan penyelenggaraan seni pertunjukan tertentu (Kusmayati, 1999: 129).

Seni Pertunjukan dalam sebuah ritual dapat berfungsi kepada beberapa pihak 
yang berkepentingan, seperti bagi para penonton dan penyelenggara. Penonton dalam hal ini dibedakan menjadi dua, pertama adalah jemaah atau peserta upacara. Mereka memposisikan dirinya sebagai pelaku atau peserta ritual dan juga sebagai penikmat atau penonton. Kedua adalah masyarakat yang berada di luar kepentingan upacara namun ikut hadir jika lokasi ritual dilaksanakan di tempat terbuka. Kedua kelompok tersebut dapat berbaur menjadi satu pada acara dan waktu yang sama. Ritual tersebut dapat menjadi sesuatu yang berarti bagi beberapa pihak, masing-masing dapat memperoleh kepuasan batin ketika melaksanakannya tanpa ada batasan-batasan. Ritual yang biasa dilakukan oleh masyarakat di Kecamatan Pakis yang berkaitan dengan pertanian di antaranya dilakukan pada:

a). Aum Tandur, yaitu ritual permohonan kepada Dewi Sri yang diyakini sebagai dewi kesuburan penabur benih padi. Tujuannya agar padi dan sayur-mayur yang ditanam oleh petani bisa subur dan tidak diserang hama atau binatang perusak. Upacara diselenggarakan setiap habis masa tanam dengan melakukan sesaji dan pertunjukan kesenian atau wayang kulit semalam suntuk. Kegiatan ini biasa dilakukan hampir di seluruh desa yang tersebar di Kecamatan Pakis.

b). Aum Panen, yaitu upacara syukuran sebagai ungkapan terimakasih atas hasil panen yang diberikan setiap habis panen kepada Dewi Sri yang oleh orang jawa diyakini sebagai Dewa Padi. Ia adalah pembawa berkah dalam bidang pertanian, dengan melaksanakan selamatan agar hasil pertanian yang dihasilkan lebih bermanfaat. Pada umumnya kegiatan ini diawali dengan kenduri dan makan bersama seluruh warga sebagai ungkapan rasa syukur atas berkah yang diberikan Tuhan YME, melalui hasil panen masyarakat sambil dihibur dengan beberapa kesenian yang ada di masing- masing desa. Kegiatan ini biasa dilakukan hampir di seluruh desa yang tersebar di Kecamatan Pakis.

c). Bersih Desa, adalah upacara yang dilakukan oleh masyarakat hampir diseluruh desa di Kecamatan Pakis yang bertujuan untuk membersihkan desa dari segala pengaruh jahat atau negatif yang dapat mengganggu keberlangsungan desa. Biasanya setelah melaksanakan bersih desa diteruskan dengan pentas seni oleh warga, seperti ada keharusan untuk mementaskan kesenian yang ada di wilayahnya untuk dipentaskan setelah bersih desa.

d). Nyadran Kali, yaitu ritual yang rutin dilaksanakan setiap BulanSapar ini diawali dengan doa bersama yang dipimpin oleh seorang juru kunci di sumber mata air yang dipercayai sebagai sumber kehidupan bagi warga Kecamatan Pakis, sebab dahulu beberapa desa pernah hidup tanpa air sama sekali, kemudian sesepuh desa berdoa dan menemukan sumber mata air yang kemudian disalurkan ke beberapa desa agar bias dimanfaatkan. Beberapa tahun terakhir ritual tersebut telah menjadi sebuah tradisi yang dilestarikan oleh masyarakat sebagai ucapan terimakasih kepada Tuhan Yang Maha Esa, atas berkah air yang melimpah di wilayah Gunung Merbabu. Kegiatan ini biasa dilakukan di beberapa desa yang tersebar di Kecamatan Pakis, khususnya Desa Muneng Warangan, Desa Ketundan, dan Desa Gondangsari.

e). Nyadran Makam, yaitu merupakan sebuah ritual yang diselenggarakan di makam setiap Bulan Ruwah. Ditujukan untuk doa bagi para leluhur cikal bakal dari beberapa desa yang ada di Kecamatan Pakis danjuga orang-orang yang dikuburkan di makam tersebut. Tujuannya dimaksudkan untuk mendoakan agar arwah leluhurnya selalu diterima di sisi Tuhan Yang Maha Esa, tetapi sebagai pelestarian penghormatan kepada arwah leluhur. Kegiatan ini biasa 
dilakukan hampir di seluruh desa yang tersebar di Kecamatan Pakis.

Ritual lain yang berhubungan dengan hari besar Islam adalah pada hari raya idul fitri yaitu syawalan. Salah satunya adalah Sungkem Telompak, yaitu hampir sama dengan Nyadran Kali, sebab melakukan ritual doa di depan sumber mata air yang ada di Dusun Gejayan, Desa Banyusidi yang biasa dilakukan setiap tanggal lima bulan Syawal. Secara fisik saat tradisi berlangsung, masyarakat dari Dusun Keditan berhalal-bihalal bertemu di dusun Gejayan, namun secara spiritual mereka menjalankan semangat untuk melestarikan lingkungan terutama mata air 'telompak'. Secara umum, setelah diadakan ritual tersebut, selalu dilanjutkan dengan adanya pertunjukan kesenian baik dari dalam desa maupun luar desa.

Kelompok lain adalah pada pihak penyelenggara, walaupun ritual dilakukan di tempat-tempat yang sudah ditentukan, namun semua itu pastilah ada pihak yang bertanggung jawab untuk menjalankan ritual tersebut dengan beberapa masalah teknis. Mereka juga turut menyiapkan kelengkapan pelaksanaan ritual, termasuk memberikan sumbangan pikiran, tenaga, bahkan biaya yang dibutuhkan. Mereka bekerja bersama-sama tanpa membedabedakan untuk terwujudnya kegiatan secara gotong-royong.

Bagi para pemain atau pelaku maupun juga penyelenggara kepuasan dapat mereka peroleh dengan cara telah berpartisipasi mengikuti ritual tersebut, sehingga di benak mereka ada rasa tentram dan nyaman telah ikut serta dalam meneruskan ritual yang sudah dilaksanakan sejak nenek moyang sebelumnya. Ada rasa bangga karena telah ikut melestarikan budaya bangsa yang patut untuk diteruskan. Seperti yang diungkapkan oleh Budi (13 tahun) salah seorang penari Soreng yang ikut dalam ritual Nyadran Kali berikut ini:

\begin{abstract}
"Saya itu sudah ikut bangga dan senang mbak, kalo ikut nari di Nyadran Kali. Bisa terpilih nari di situ saja harus nunggu saya sampai SMP padahal saya sudah senang ikut bapak ritual itu dari kecil. Apalagi ini juga bisa sekaligus ikut melestarikan tradisi"1
\end{abstract}

Hal serupa juga diungkapkan Lurah Desa Banyusidi Riyadi (35 tahun) mengenai ritual Sungkem Telompak. Satu hal yang bisa diambil manfaat dengan adanya ritual adalah dapat melestarikan lingkungan dengan merawat tempat-tempat yang dianggap sakral.

"Saya sebagai lurah itu seneng sekali ketika warga saya ikut terlibat dalam ritual sungkem tlompak ini, sebab secara tidak langsung mereka juga ikut menjaga alam dengan rutin membersihkan arena ritual atau sumber air agar tidak dibiarkan begitusaja oleh rumput liar. Adanya ritual ini sekaligus mereka melestarikan tradisi tetapi juga melestarikan alam." ${ }^{2}$

Berbagai fungsi dan manfaat dari beberapa lokasi yang disakralkan untuk diadakan ritual yang rutin diselenggarakan setiap tahunnya dengan menggunakan seni pertunjukan sebagai salah satu medianya. Seni pertunjukan yang berfungsi sebagai ritual tidak sebatas pada melengkapi apa yang dipersyaratkan dalam ritual namun juga membawa manfaat lain yaitu sebagai pelestarian tradisi dan alam.

Media transmisi dapat dilakukan melalui masyarakat secara umum atau dimulai dalam lingkup kecil yaitu keluarga. Selain melalui ritual, proses pewarisan dilakukan dengan mulai mengenalkan dan mendekatkan generasi penerus dalam hal ini adalah anak-anak dengan seni. Masyarakat lereng Gunung Merbabu adalah masyarakat pedesaan yang berbeda dengan gaya hidup masyarakat perkotaan. Ketika di kota atau di tempat lain terdapat sekolah atau sanggar

\footnotetext{
${ }^{1}$ Wawancara dengan Budi di Desa Banyusidi, Kecamatan Pakis, Magelang, tanggal 18 Juni 2010.

${ }^{2}$ Wawancara dengan Lurah Riyadi di Desa Banyusidi, Kecamatan Pakis, Magelang, tanggal 18 Juni 2010.
} 
yang secara rutin mendatangkan guru untuk mengajarkan beberapa tarian untuk dihafal dan diikuti yang bisa saja kesehariannya anak-anak tidak pernah mendengar musik atau melihat pertunjukan secara intensif.

Transmisi kesenian dapat melalui dia kategori, yaitu melalui pendidikan formal dan pendidikan non formal. Proses formal adalah proses pendidikan yang dilakukan resmi oleh lembaga yang disahkan oleh pemerintah seperti sekolah dan harus taat pada kurikulum yang berlaku. Proses non formal adalah proses yang dilakukan dalam suatu lembaga tidak resmi dan aturan kurikulum tidak terlalu ketat (Djelantik, 1993: 16). Di Bali sebagai contoh, teknik penerapan materi kesenian dalam hal ini tari dibagi menjadi tiga, pertama yaitu imitasi dengan menyontoh dan si murid hanya menirunya. Kedua adalah koreksi yaitu memperbaiki yang salah, menuntun, dan mengarahkan secara tegas, dan yang terakhir adalah moulding yaitu mengubah bentuk agar tegak dan membentuk sesuai kehendak sang guru (Djelantik, 1993: 32).

Di lereng gunung merbabu, hampir sebagian besar proses trasnmisi adalah melalui sistem non-formal tanpa pendidikan secara resmi. Meskipun pada akhirnya pada saat latihan bersama-sama ada salah seorang yang lebih ahli atau yang sudah terbiasa dengan kesenian tersebut mengikuti latihan dan memberikan contoh jika ada anggota yang tidak tepat gerakannya. Proses pengajaran yang harus mendatangkan guru secara khusus biasanya adalah pada saat penyampaian bentuk kesenian baru, seperti yang terjadi pada proses pembelajaran kesenian Gupolo Gunung di Desa Banyusidi. Waskito sebagai penata gerak mengajarkan kepada pemuda-pemuda yang berniat menjadi anggota Gupolo Gunung.

Di desa khususnya lereng Gunung Merbabu generasi penerus atau anak-anak hampir setiap hari bersinggungan langsung dengan kesenian, sebab di desa suasana berkesenian lebih dapat dirasakan secara intensif. Kreativitas masyarakat pedesaan dapat dikatakan lebih menonjol sebab mereka melakukannya tanpa beban atau paksaan apapun, sehingga karya yang keluar lebih bersifat pengungkapan ekspresi kegembiraan. Motivasi masyarakat atau pelaku seni sangat sederhana, karena mereka pada umumnya tidak mampu melanjutkan pendidikan di sekolah atau perguruan tinggi seni, maka jika mereka tidak berkarya, maka siapa yang akan mengenal mereka.

Jiwa untuk dapat merasakan apa yang dilihat dan didengarkan secara langsung akan lebih tertanam, dibandingkan hanya beberapa saat latihan atau menonton pertunjukan. Pembicaraan sehari-hari yang juga tidak lepas dari kesenian juga menambah masyarakat atau generasi penerus akan selalu dekat dengan dunia seni. Anak-anak di Kecamatan Pakis ini ketika sudah hari sabtu atau minggu atau musim liburan akan sibuk mencari jadwal pentas atau pertunjukan yang akan diadakan dimana, kapan, jam berapa dan lain sebagainya. Terlebih ketika mereka sudah mempunyai idola sebuah grup kesenian, maka ia akan datangi lokasi pertunjukannya. Kalaupun itu jauh, maka ia akan mengajak orang yang lebih dewasa untuk mengantar dan menemaninya. Seperti yang diungkapkan Febri (9 tahun):

\section{"Aku itu paling suka sama Soreng yang dimainkan oleh grup dari jayan, banyak yang nari soreng tapi paling suka yang dari jayan. Soalnya musiknya lebih meriah, gerakannyajuga lebih kompak. Gagah banget kalo liat rasanya pengen ikut nari. Jadi kali ada acara tak suruh bapak atau kakaku anterin."}

Proses pewarisan masyarakat lereng gunung lebih terjadi begitu saja terkadang tanpa direncanakan lebih dulu. Anak-anak tidak sengaja ikut terlibat dalam proses berkesenian karena lingkungan yang mendukung, seperti keluarga atau teman-temannya yang ikut

\footnotetext{
${ }^{3}$ Wawancara dengan Febri, di Desa Warangan, Kecamatan Pakis, Magelang, Tanggal 5 Mei 2010
} 
terlebih dahulu, atau karena lokasi rumah dekat dengan sanggar seni. Mereka secara tidak langsung melihat, mendengar, dan merasakan seni itu hadir dalam kehidupan mereka. Intensitas mereka berpartisipasi dalam setiap kegiatan mulai dari latihan sampai ke pentas itu akan menimbulkan rasa yang berbeda bagi mereka. tidak jarang anak-anak yang belum sekolah pun langsung menggerakkan kaki, tangan, atau kepala ketika mendengar gamelan dimainkan.

Menurut Desmon Morris dapat dikatakan bahwa proses transmisi dapat terjadi pada absorbed actions dan trained actions atau perpaduan antara keduanya (Morris, 1977: 18-23). Absorbed actions adalah kegiatan yang dilakukan akibat mencontoh dari orang lain, sementara trained actions adalah kegiatan yang didapat melalui pembelajaran ataupun praktek terlebih dahulu. Proses transmisi dapat merupakan perpaduan antara keduannya yaitu melalui proses genetik, observasi pribadi, penyerapan dari lingkungan sosial, dan melalui latihan atau belajar. Oleh karena itu, seseorang mendapatkan sesuatu sebagai proses pewarisan dapat melalui berbagai cara, tidak hanya secara genetik namun yang terpenting adalah lingkungan sosial dan proses belajar.

Haviland secara gamblang menjelaskan bahwa semua kebudayaan manusia dengan segala unsurnya termasuk didalamnya kesenian merupakan hasil dari belajar, bukan karena warisan biologis (Haviland, 1985: 338). Anak-anak atau generasi penerus bukan semata-mata memiliki 'darah seni' yang diwariskan, tetapi lebih pada situasi atau suasana yang kondusif untuk kegiatan berkesenian. Proses pewarisan juga dapat terjadi pada saat pertunjukan merupakan proses trasnformasi pengetahuan secara langsung dan teknik atau gaya menari yang langsung dapat dilihat.

Anak-anak tidak selalu menjadi objek pewarisan bahwa masyarakat umum juga bisa mempelajari kesenian yang berkembang di daerahnya. Pemuda-pemudi bahkan bapak-bapak, maupun ibu-ibu juga bisa belajar untuk bisa menari dan terlibat dalam sebuah kelompok kesenian. Ada sedikit perbedaan anak-anak yang memang sudah memiliki bakat, hanya dari sering menonton dan mencoba sendiri sebuah tarian, maka ia dapat langsung bergerak mengikuti irama sudah langsung dapat menari. Namun untuk usia remaja ke atas, maka diperlukan latihan atau guru secara khusus untuk berbagi ilmu dan teknik gerak dalam suatu kesenian. Akibat seringnya terlibat dalam sebuah kesenian, maka di situlah terjadi tradisi bagi individu ataupun masyarakat setempat untuk hidup berdampingan dengan kesenian.

Transmisi tradisi juga dapat dikatakan sebagai invented tradition yang dapat diartikan tradisi temuan atau tradisi yang ditemukan, yaitu tradisi yang nyata ditemukan, dikonstruksi, dan secara formal dilembagakan. Dalam hal ini kesenian tradisional yang diwariskan kepada generasi penerus diaselenggarakan secara rutin sehingga menjadi sebuah tradisi. Seperti contoh pada sebuah ritual, yang pada awalnya kesenian bukan merupakan suatu keharusan namun diadakan oleh masyarakat setempat bahwa sebuah ritual tertentu diwajibkan ada salah satu kesenian tertentu yang dapat dimaksudkan agar kesenian tersebut tetap lestari karena paling tidak diperkenalkan kepada setiap generasi untuk mempertahankan kesenian tersebut. Meskipun demikian sebuah tradisi yang baru tidak dapat meninggalkan apa yang sudah menjadi bagian dari tradisi yang lama, hanya saja sudah ada kesepakatan bahwa tradisi tersebut sudah ada penyesuaian dengan keadaan yang sekarang.

Kreativitas sudah mulai bisa di buktikan disini, ketika masyarakat tidak hanya menerima apa yang sudah ada di generasi sebelumnya. Masyarakat atau pelaku seni juga harus mampu memberikan inovasi terhadap sebuah kesenian yang diwariskan untuk 
dapat mengikuti perkembangan agar tidak mati ditelan zaman. Proses transmisi juga dapat dijadikan sarana untuk menghasilkan sesuatu karya yang baru tanpa meninggalkan tradisi yang sebelumnya.

\section{SIMPULAN}

Ritual sebagai salah satu media trasnmisi atau pewarisan tradisi yang paling kuat. Transmisi tidak hanya berhasil hanya dengan teknis bagaimana ia dapat terus diwariskan, tetapi juga yang lebih penting adalah bagaimana transmisi peristiwa yang masih bisa berlangsung terus-menerus. Ritual yang dilakukan oleh generasi sebelumnya dapat terus dilakukan oleh generasi penerus tanpa ada unsur paksaan dari kedua belah pihak akan menjadikan proses transmisi berjalan lancar. Masyarakat akan terus melaksanakan apa yang sudah menjadi kewajibannya dengan terus melestarikan apa yang sudah ada dan menjadi kebiasaannya.

Ritual yang biasa dilakukan di wilayah lereng Gunung Merbabu ini sangat dekat dengan unsur kesenian desa yang juga dilibatkan dalam setiap ritual. Hal ini menajdi salah satu cara untuk melestarikan kesenian tradisional yang sudah ada agar lebih dapat berkembang dengan dipentaskan setiap ritual diadakan. Beberapa pentas kesenian seperti soreng, topeng ireng, gupolo gunung, warok dan lain sebagainya ini juga menjadi salah satu daya tarik bagi warga masyarakat baik pelaku ritual maupun penonton untuk mengikuti ritual. Secara otomatis kreativitas pelaku seni juga menjadi faktor penting terciptanya suasana pertunjukan yang menarik dan tidak monoton dari tahun ke tahun. Oleh karena itu, ritual juga dapat menjadi salah satu media transmisi kreativitas seni yang itu semua dilakukan oleh masyarakat dan untuk masyarakat agar tradisi yang sudah ada tidak mati atau hilang ditelan jaman yang semakin modern. Diperlukan juga bantuan dari berbagai pihak agar ritual dan kesenian menjadi salah satu tradisi yang terus dapat dilestarikan.

\section{DAFTAR PUSTAKA}

Atmosudiro, S. dkk., 2001, Jawa Tengah: Sebuah Potret Warisan Budaya, Suaka Peninggalan Sejarah dan Purbakala Propinsi Jawa Tengah dan Jurusan Arkeologi Fakultas Ilmu Budaya Universitas Gadjah Mada.

Brandon, J. R., 2003, Jejak-Jejak Seni Pertunjukan di Asia Tenggara, Terj. R.M. Soedarsono, Bandung: P4ST UPI.

Djelantik, A.A.M, 1993, "Peranan Guru Seni Non Formal Dalam Masyarakat Suku Bangsa" dalam Mudra, Jurnal Seni Budaya, Denpasar: STSI Press edisi Februari.

Firmansyah, 2007, Mengelola Partai Politik, Komunikasi dan Positioning Ideologi Politikdi Era Demokrasi, Jakarta: Yayasan Obor.

Geertz, C., 1976, Involusi Pertanian: Proses Perubahan Ekologi di Indonesia, Jakarta: Bhatara Karya Aksara.

Haviland, W.A., 1985, Antropologi Jilid I, Terj. R.G.Soekadjo, Jakarta: Erlangga.

Inkeles, A., 1983, "Modernisasi Manusia" dalam Ed. Myron Weiner Modernisasi Dinamika Pertumbuhan, Yogyakarta: Gadjah Mada University Press.

Koentjaraningrat, 1990, Sejarah Teori Antropologi II, Jakarta: Universitas Indonesia Press.

Kusmayati, A.M., Hermien, 1999, “Seni Pertunjukan Upacara di Pulau Madura 1980-1998", disertasi untuk mencapai derajat S-3, Program Pascasarjana Universitas Gadjah Mada, Yogyakarta.

Mardimin, J.,dkk., 1994, Jangan Tangisi Tradisi, Yogyakarta: Kanisius.

Masunah, J., 2003, “Menegakan Benang Basah? Pewarisan Tari Topeng Di Desa Astana Langgar, Kecamatan Losari, Kabupaten Cirebon", Seni dan Pendidikan Seni, Sebuah Bunga Rampai, ed R.M.Soedarsono, Bandung: P4ST UPI.

Morris, D., 1977, Manwatching: A Field Guide to Human Behavior, New York: Harry N. Abrams, Inc. 
Paeni, M., 1995, “Pengertian, Kedudukan, Hubungan Timbal Balik serta Fungsi Kesenian Nasional dan Kesenian Daerah," (Makalah pada Konggres Kesenian Indonesia I.
Sedyawati, E., 1985, “Keindahan Apa yang Diharapkan?", Paper dalam Sarasehan Wayang Orang.

Shils, E., 1981,Tradition, Chicago: The University of Chicago Press. 